\title{
前立腺囊胞性腺腫の一例
}

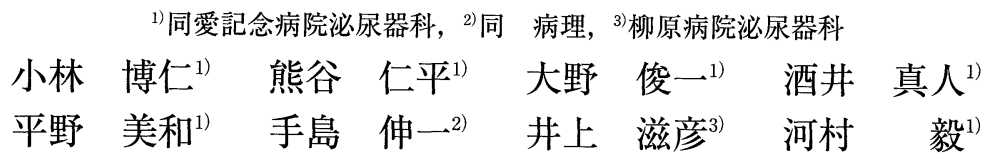

\section{A CASE OF PROSTATIC CYSTADENOMA}

\begin{abstract}
Hirohito Kobayashi $^{1)}$, Jinpei Kumagai ${ }^{1)}$, Shunichi Ono ${ }^{1)}$, Masato Sakai ${ }^{1)}$, Yoshikazu Hirano ${ }^{1)}$,
Shinichi Teshima ${ }^{2)}$, Shigehiko Inoue ${ }^{3)}$ and Takeshi Kawamura ${ }^{1)}$

Department of Urology, The Fraternity Memorial Hospital ${ }^{11}$, Department of Pathology, The Fraternity Memorial Hospital ${ }^{22}$,

Department of Urology, Yanagihara Hosipital ${ }^{3)}$
\end{abstract}

We report a case of prostatic cystadenoma. A 81-year-old man visited our hospital with the chief complaint of urinary difficulty. RUG and DIP showed bladder and prostatic urethra deviated to the left side. TRUS, CT and MRI revealed multilocular cyst in the pelvic cavity. Resection of the cystic wall was performed under the diagnosis of pelvic cyst. The cysts were originated from the right side of the prostate and adhered with the bladder severely. The histopathological diagnosis was prostatic cystadenoma.

Fortyfive cases of prostatic cyst in the Japanese literature are reviewed.

Key words : Prostatic cyst, PSA stain, Prostate cancer

\begin{abstract}
要旨：症例は 81 歳男性. 1999 年 1 月 14 日に排尿困難を主訴に当科受診. 経直腸的超音波検查上, 前立 腺に接して長径 $4 \mathrm{~cm}$ の多房性囊胞を認めたが, 本人精查希望せず放置していた. 2002 年 8 月頃より排尿 困難が悪化，尿閉となり精査目的に 9 月 10 日入院となる. RUG，DIP で膀胱，前立腺部尿道の左側への 圧排を認め, CT では骨盤内に径 $12 \times 7 \mathrm{~cm}$ の多房性囊胞を認めた. その他に骨盤 MRI, リンパ管シンチ, 精管造影, 注腸造影等施行するも, 骨盤内露胞の由来は確定できなかった. PSA 3.7ng/ml, CEA 1.2ng/ $\mathrm{ml}$ と正常であったが, CA19-9 は 111.4U/ml と高值であった. 排尿状態改善のため 10 月 1 日骨盤内囊胞 摘除術施行. 病理組織診断は前立腺囊胞性腺腫であった. 術後排尿状態は良好となり, 現在外来経過観 察中である.

キーワード : 前立腺囊胞, PSA 染色, 前立腺癌
\end{abstract}

\begin{abstract}
緒言
骨盤内臟器の種々の画像診断が頻繁に行われるよう になった現在においても前立腺囊胞は比較的稀な疾患 である，中には前立腺癌を合併している症例も報告さ れているため, 癌合併の有無が臨床上問題となる. 今 回我々は前立腺豊胞性腺腫の一例を経験したので, 若 干の文献的考察を加え報告する.
\end{abstract}

\section{症例}

患者：81 歳, 男性.

主訴：排尿困難.

既往歴 : 脳梗塞, 糖尿病, 高血圧.
家族歴：特記すべきことなし.

現病歴：1999 年 1 月 14 日に排尿困難を主訴に当科 受診. 経直腸的超音波検查 (以下 TRUS) 上, 前立腺 に接して径 $4 \mathrm{~cm}$ の多房性囊胞を認めるも, 本人が精査 を希望せず放置していた. 2002 年 8 月頃より排尿困難 が悪化し，9月 7 日に尿閉となり 9 月 10 日精查目的に 入院となった.

入院時現症: 右下腹部に小览頭大の腫瘤を触知. 前 立腺は直腸指診上 3.5 横指, 弾性軟, 表面平滑であっ た。

入院時検査: 血液一般・生化学的検査, 尿検查では 
図 1 尿道造影：膀胱，前立腺部尿道は左側に圧排さ れ，前立腺部尿道の延長を認めた。

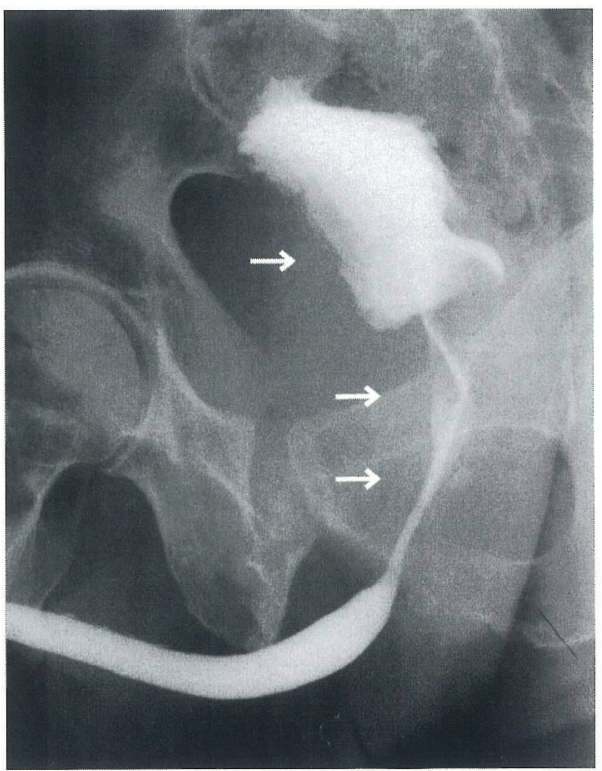

困 2 骨盤 MRI : T2 強調画像. 骨盤内に多房性囊胞を 認め, 膀胱，前立腺は左側に圧排されていた。

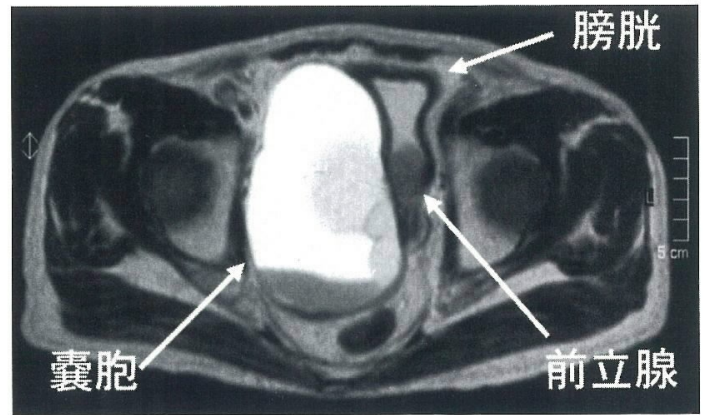

異常を認めなかった。腫瘍マーカーはPSA $3.7 \mathrm{ng} / \mathrm{ml}$, CEA 1.2ng/ml と正常であったが，CA19-9 は 111.4 U/ $\mathrm{ml}$ と高値を示した。

画像所見：経腹的超音波検査，TRUS で骨盤内に径 $11 \times 9 \times 8 \mathrm{~cm}$ 大の多房性囊胞を認めるが，壖胞が巨大 なため前立腺との関連は描出できなかった。逆行性尿 道造影 (図 1) では膀胱, 前立腺部尿道は左側に圧排さ れており，前立腺部尿道の延長と扁平化を認めた。静 脈性尿路造影では膀胱は左側へ著明に圧排されていた が，上部尿路に異常は認めなかった。骨盤 CTは径
四 3 病理組織像：HE染色（A）では囊胞壁は円柱上 皮で亭打ちされており，前立腺組織を認めたＰSA 染色 (B)では囊胞壁は全体的に染色され，囊胞は前 立腺由来であると診断された。

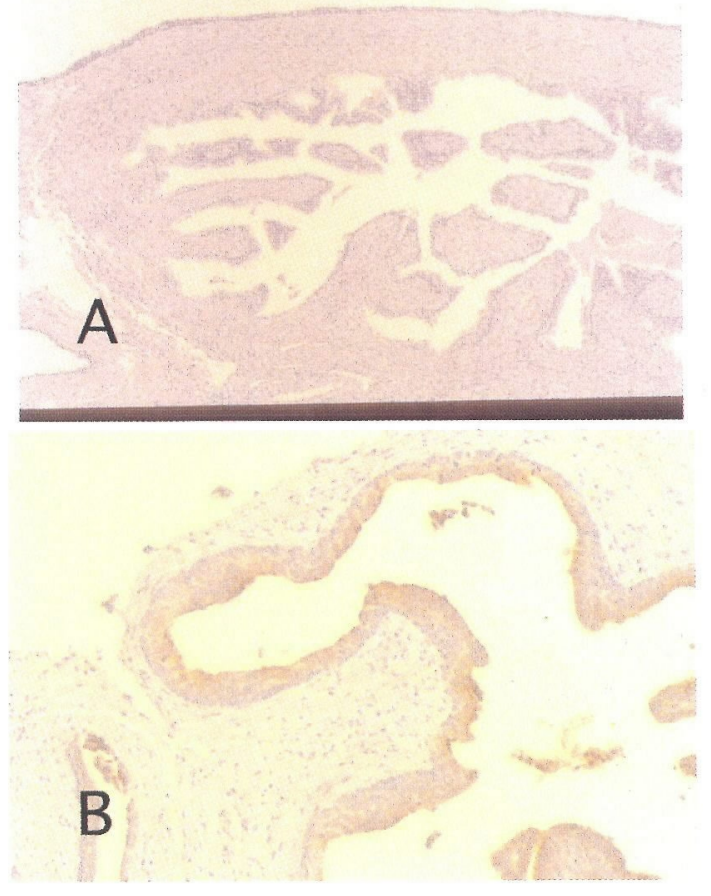

$12 \times 7 \mathrm{~cm}$ 大の多房性囊胞と左側に圧排された前立腺， 膀胱を認めた。明らかなリンパ節腫大は認めなかった。 骨盤 MRI では血液成分を含む T1 高信号, T2 低信号 の䵍胞と血液成分を含まない T1 低信号, T2 高信号の 囊胞が混在する多房性の囊胞を認めた（図 2)。精管造 影は右精管が途絶していた。

以上の結果より骨盤内囊胞と䛦断し 2002 年 10 月 1 日囊胞摘除術を施行した。

術中所見：下腹部正中切開にて骨盤腔内に到達。䘫 胞は骨盤壁からの剥離は容易であったが，膀胱とは非 常に強く癒着しており，また前立腺と囊胞壁は境界不 明瞭であったため前立腺の一部を含めて切除した。

囊胞内溶液所見: 内溶液量は $470 \mathrm{ml}$, 色調は黄色透 明から茶褐色混濁。生化学検査では比重 1.034 , 蛋白 $4.68 \mathrm{~g} / \mathrm{dl}$, 糖 $25 \mathrm{mg} / \mathrm{dl}$, Cre $0.9 \mathrm{mg} / \mathrm{ml}$, BUN $21.5 \mathrm{mg} /$ $\mathrm{ml}$, LDH $12,045 \mathrm{IU} / l$, Na $139 \mathrm{mEq} / l, \mathrm{~K} 3.9 \mathrm{mEq} / l$, $\mathrm{Cl} 104 \mathrm{mEq} / \mathrm{l}$ であり LDH の高值を認めた。細胞診 classII. PSA : 15,855ng/ml, CEA : $313.4 \mathrm{ng} / \mathrm{ml}$, 
表 1 通常の前立腺囊胞と前立腺癌合併囊胞の比較

\begin{tabular}{|c|c|c|}
\hline & 前立腺囊胞（19 例） & 癌合併囊胞（26 例） \\
\hline 年齢 & $33 \sim 81$ 歳（平均 52.1 歳） & $54 \sim 87$ 歳（平均 73.0 歳） \\
\hline 最大径 & $1.5 \sim 20 \mathrm{~cm}$ (平均 $5.8 \mathrm{~cm}, 18$ 例) & $2.1 \sim 15 \mathrm{~cm} （$ 平均 $7.8 \mathrm{~cm}, 18$ 例 $)$ \\
\hline 血清 PSA & $1.0 \sim 6 \mathrm{ng} / \mathrm{ml}$ (平均 $3.3 \mathrm{ng} / \mathrm{ml}, 5$ 例) & $2.3 \sim 1,300 \mathrm{ng} / \mathrm{ml}$ (平均 $178.7 \mathrm{ng} / \mathrm{ml}, 21$ 例) \\
\hline 内溶液性状 & 血性～暗褐色（5 例） & 血性～暗褐色（21 例） \\
\hline 内溶液細胞診 & 陽性例なし（11 例中） & 陽性 5 例（19 例中） \\
\hline 内溶液 PSA & $6,850 \sim 59,900 \mathrm{ng} / \mathrm{ml} \quad(3$ 例 $)$ & $533 \sim 390,000 \mathrm{ng} / \mathrm{ml}$ (14 例) \\
\hline
\end{tabular}

CA19-9 : 23,584U $/ \mathrm{ml}$ と高值であった.また, 内溶液に は精子を認めなかった。

病理組織学的所見：多房性囊胞状の病変であった. 囊胞壁は円柱上皮, 移行上皮, 一部重層扁平上皮が裏 打ちしており, 前立腺組織と見られる腺構造と結石を 認めた. PSA 染色で囊胞上皮が染色されたため, 前立 腺由来であると診断した（図 3 )。また，術前血清 CA19-9 が高值であったためCA19-9 染色を施行した. 囊胞壁の一部が染色されたので自験例における血中お よび囊胞内溶液の CA19-9 の由来は前立腺囊胞と思わ れた。明らかな癌細胞を認めず，囊胞壁に腺構造を認 めたため前立腺囊胞性腺腫と診断した.

術後経過: 術後経過は良好で, 排尿状態も改善され た. 尿道造影では前立腺部尿道, 膀胱共に左側への圧 排は解除されていた。術後腫瘍マーカーは PSA 4.2ng/ $\mathrm{ml}$, CEA 0.7ng/ml, CA19-9 62.4U/ml で CA19-9 の 著明な低下を認めた。現在外来経過観察中であるが, 囊胞の再発は認めていない.

\section{考察}

前立腺囊胞は臨床上比較的稀な疾患である. Wesson $(1925 \text { 年 })^{1)}$ によと 1742 年に Morgagni が解剖体に 認めたのが最初の前立腺囊胞の報告とされている.

Emmett ら（1936 年 ${ }^{2)}$ は大きさ $0.75 \mathrm{~cm}$ 以上のものを 前立腺囊胞, $0.75 \mathrm{~cm}$ 以下は腺腔の拡張とし, 先天性の ものとしてミュラー管・ウォルフ管の遺残, 後天性の ものとして貯留性囊胞, 囊胞性腺腫, 前立腺癌合併囊 胞，エキノコックス，ビルハルッ住血吸虫による囊胞 に分類している. 1974 年に棚橋ら ${ }^{33}$ は, Emmett らの分 類には発生学的に異なるものが含まれていること，吸 虫による囊胞は稀であることより, 先天性前立腺囊胞, 貯留性囊胞, 囊胞性腺腫, 前立腺癌合併囊胞の 4 型に 分類しており，現在ではこの分類が合理的であると考 えられている.

前立腺は発生過程において先天的に囊胞を形成する
可能性があることは考えられるが, きわめて稀であ

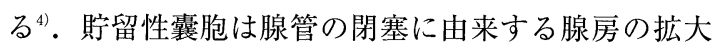
によっておこるといわれており，囊胞性腺腫は囊胞が 多房性で内膜上皮に腺組織がみられるといわれるが両 者の鑑別は困難な場合が多い，本症例の場合，囊胞が 多房性であり囊胞壁に腺構造を認めたこと, ミュラー 管囊胞等との鑑別として ${ }^{5)} \mathrm{PSA}$ 染色で囊胞上皮が染色 されたことより前立腺囊胞性腺腫と診断された。

本邦における前立腺囊胞は, 我々が調べ得た限りで は本症例も含めて 45 例が報告されている(3) 557) 14). 内 訳は貯留性囊胞 13 例, 䡛胞性腺腫 3 例, 前立腺癌合併 囊胞 26 例，不明 3 例である．年齢は 33〜 87 歳（平均 64.2 歳), 最大径は $1.5 \sim 20 \mathrm{~cm}$ (平均 $6.8 \mathrm{~cm}$, 記載なし 9 例), 主訴として尿閉や排尿困難, 頻尿など排尿状態 に関することが多く，肉眼的血尿を認めた 5 例は全例 前立腺癌を合併していた．診断方法としては直腸診， 超音波, CT, MRI な゙が用いられている.

前立腺囊胞の臨床上の問題点として前立腺癌合併の 有無がある. 前立腺癌に伴う前立腺囊胞については, 貯留性囊胞の囊胞上皮が悪性化した場合と前立腺癌が 中心壊死または出血をきたし仮性囊胞を形成した場合 の 2 通りが考えられる ${ }^{6}$. 自験例では摘出標本に癌細 胞を認めなかった．表 1 に自験例を含め通常の前立腺 囊胞と前立腺癌合併囊胞の症例を比較したものを示 す. 平均年龄は前立腺癌合併囊胞が高く, 最大径に関 しては両者にあまり差は認めなかった. 血清 PSA は通 常の前立腺囊胞はほぼ正常範囲内であり, 癌合併囊胞 では高值をとることが多いが，正常範囲内であった症 例も報告されている. 囊胞内溶液の PSA 值は, 通常の 前立腺囊胞と癌合併囊胞で記載のあった全症例で高值 であった，癌合併囊胞の内溶液細胞診は 5 例が陽性を 示すのみで, 他に報告されている 14 例は陰性であっ た.

これまでの報告では前立腺癌が合併している場合， 
内溶液が血性を呈したり, PSA が高値を示すことが鑑 別点として挙げられているが, 通常の前立腺囊胞でも 内溶液の性状が血性や PSA 高值をとることがあるた め, 囊胞内溶液による診断の意義は低いと考えられた. 自験例では術前の PSA 值が正常範囲内であり, 前立腺 の直腸指診，画像診断で悪性所見が認められなかった ため囊胞穿刺は行わなかった.

以上より癌合併の有無に関して診断することは困難 なことが多く, 確定診断は病理組織学的診断に頼らざ るを得ないと考えられる．現在までに治療法として経 腹, 経会陰的手術や経尿道的手術, 囊胞穿刺などが報 告されているが, 前立腺囊胞を認めた際には, 小さい 囊胞であっても PSA 測定や画像検査を施行し, 癌合併 の疑いがあれば前立腺生検を行い, 囊胞穿刺および手 術の適応に関して慎重に検討することが必要であると 考えられた。

\section{文献}

1) Wesson, M.B. : Cysts of the prostate and urethra. J. Urol., 13, 605-632, 1925.

2) Emmett, J.L. and Braasch, W.F.: Cysts of the prostate gland. J. Urol., 36, 236-249, 1936.

3）棚橋善克, 渡辺 決, 猪狩大陸, 原田一哉, 島 正 美, 加藤善朋 : 前立腺貯留性囊腫の 1 例. 西日泌 尿, 36, 83-87, 1974.

4）森本信二, 奥野哲男, 増田 均, 笠松得郎, 鈴木 滋: 前立腺囊胞腺腫の 1 例. 泌尿紀要, 40,629631, 1994.
5）今園義治, 今村厚志：前立腺囊胞性疾患の 2 例. 西 日泌尿，58, 149-152, 1996.

6) Blank, H. : La forme kystique du cancer de la prostate. J. d' Urol., 41, 13-27, 1936.

7）梶原，充, 牟田口和昭, 碓井 亞 : 多房性囊胞形成 をきたした前立腺導管癌の 1 例. 泌尿紀要，48, 557-560, 2002.

8）長野正史, 嘉川春生, 島袋浩勝, 新村研二：膀胱頚 部に発生した前立腺貯留性囊胞の 2 例. 西日泌尿, 59, 921-924, 1997.

9）山下敦史, 桜井正樹, 近藤德也, 有馬公伸：前立腺 乳頭状嚢胞腺癌の 1 例. 日泌尿会誌, 88（12）, 1028-1031, 1997.

10）高山仁志, 新井康之, 目黑則男, 前田 修, 細本 茂, 木内利明, 黒田昌男, 宇佐美道之, 古武敏彦： 囊胞状変化を伴った前立腺癌の 1 例, 泌尿紀要, 42, 977-980, 1996.

11）川上 理, 渡辺 徹, 山田拓已, 根岸壮治: 結節性 過形成を示す前立腺組織が内腔に突出した前立腺 貯留性囊胞の 1 例. 泌尿紀要, 37, 397-401, 1991.

12）渡辺 仁, 小西 平, 竹内秀雄, 友吉唯夫 : 巨大前 立腺囊胞性腺腫の 1 例. 泌尿紀要, 36, 1077-1079, 1990.

13）三枝道尚, 岸 幹雄, 公文裕巳, 松村陽右, 大森弘 之: 前立腺貯留性囊胞の 1 例. 泌尿器外科, 1 (10), 989-993, 1988.

14）沼田 功, 棚橋善克, 福崎 篤, 加藤弘彰 : 前立腺 のう腫の 2 例．西日泌尿，43, 1185-1190, 1981.

(2004 年 3 月 31 日受付, 9 月 2 日受理) 